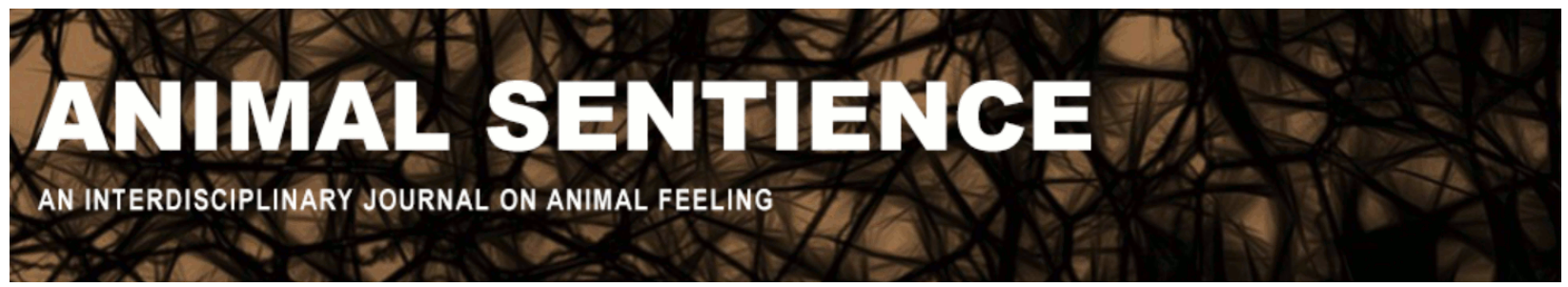

Yokawa, Ken and Baluška, František (2018) Fish and plant sentience: Anesthetized plants and fishes cannot respond to stimuli. Animal Sentience 21(6)

DOI: $10.51291 / 2377-7478.1329$

Date of submission: 2018-05-19

Date of acceptance: 2018-05-21

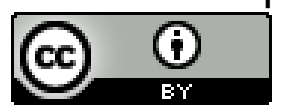

This article has appeared in the journal Animal

Sentience, a peer-reviewed journal on animal

cognition and feeling. It has been made open access,

free for all, by WellBeing International and deposited

in the WBI Studies Repository. For more information,

please contact

wbisr-info@wellbeingintl.org.

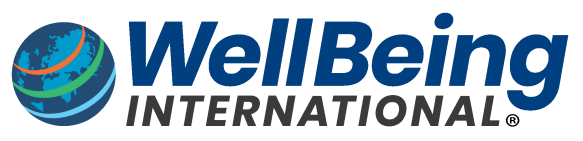

SOLUTIONS FOR PEOPLE, ANIMALS AND ENVIRONMENT 


\title{
Fish and plant sentience: Anesthetized plants and fishes cannot respond to stimuli
}

Commentary on Sneddon et al. on Sentience Denial

\author{
Ken Yokawa ${ }^{1}$ \& František Baluška² \\ ${ }^{1}$ Center for Biological Research \& Education, Utsunomiya University \\ ${ }^{2}$ Institute of Cellular and Molecular Botany IZMB, University of Bonn
}

\begin{abstract}
Recent denial of fish sentience is at variance with the fact that all living organisms need environmental awareness in order to survive in a continuously fluctuating environment. Moreover, fish sentience - like plant sentience - is also strongly supported by the sensitivity of fishes and plants to diverse anesthetics.
\end{abstract}

Ken Yokawa is assistant professor at Center for Bioscience Research and Education, Ustunomiya University. He works on root tropism and behavior, and especially the light response of roots is his main interest. He conducted anesthesia studies using plants when he was a post-doc at the University of Bonn. researchmap.jp/ken2yo/

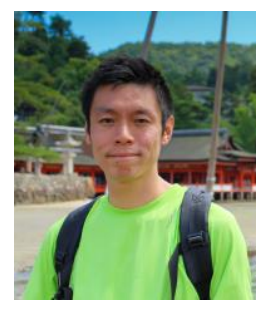

František Baluška, group leader at IZMB, University of Bonn, Germany, is interested in the integration of plant cell biology and plant physiology with plant sensory ecology and electrophysiology, generating the emerging field of plant neurobiology. He has founded and edits two new journals, Plant Signaling \& Behavior and Communicative \& Integrative Biology, as well as the Springer book series Signaling and Communication in Plants. ds9.botanik.unibonn.de/zellbio/AG-Baluska-Volkmann/

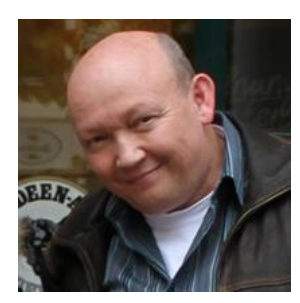

"... what is alive must sense and can be anesthetized, the rest is dead."

Claude Bernard (1878)

Anesthesia, like sentience and consciousness themselves, has long been a mysterious phenomenon in modern science (Rinaldi 2014, Koch 2018). The mechanisms that cause the loss of consciousness with diverse anesthetic compounds are still unknown.

We have recently reported that plants can be anesthetized by blocking action potentials and effects on synaptic vesicle recycling (Yokawa et al. 2018). Treatment with diethyl-ether stopped the leaf-closing movements of both Mimosa pudica, a sensitive plant, and the Venus flytrap, the well-known carnivorous plant. After removal of diethyl-ether from their treatment chamber, the plants immediately began recovering their action potentials; their response to touch was restored in $15 \mathrm{~min}$. Leaf responses to touch disappeared even when just the root part of the Mimosa pudica was submerged in lidocaine (local anesthesia). In addition, seed dormancy was prolonged under anesthesia, and seeds immediately regained germination when the anesthetics were removed. Diverse anesthetics effectively affect plant cells, immobilizing the movements of plant organs under anesthesia (Yokawa et al. 2018). We have proposed that possible targets of plant anesthesia are cellular membranes, which are fundamentally important for all living organisms. This mechanism was already suggested by 
French physiologist Claude Bernard in 1878, when he presented convincing anesthetic experiments using Mimosa plants (Bernard 1878; Grémiaux et al. 2014). In our study, we documented the effects of anesthetics on membranes of cells in the root apex transition zone, resulting in an excessive accumulation of reactive oxygen species (ROS) and aberrant endocytic vesicle recycling at the root synapses (Yokawa et al. 2018).

Similar high sensitivity to anesthetics has been reported for fishes (Neiffer and Stamper 2009, Sneddon 2012). Lopez-Luna demonstrated that administering analgesic drugs to fish alleviated their response to noxious chemicals (Lopez-Luna et al. 2017a) or noxious temperatures (Lopez-Luna et al. 2017b). When anesthetized, both plants and fishes lose their ability to respond to stimuli; their movements are lost too, and they are obviously devoid of environmental awareness. Removal of anesthetics results in rapid recovery. These data strongly support sentience in both plants and fishes (Trewavas and Baluška 2011, Calvo et al. 2017, Gagliano 2017, Sneddon et al. 2018).

It is still difficult to say whether fishes and plants feel pain or have nociception. However, it is known that plants respond quickly and sensitively to wounding and initiate woundhealing processes immediately. Once the plant body is physically damaged, wound-mediated cellular signaling is rapidly initiated, transferring danger information throughout the entire plant body. This 'danger' signal is also communicated to other neighboring plants by secretions and airborne chemicals. This changes the status of plant cells as well as the tissues of adjacent plants, allowing them to cope with upcoming threats. Moreover, plants endogenously produce multiple anesthetics of their own (Tsuchiya 2015, 2017) under conditions of stress or wounding (Baluška et al. 2016); these too have membranes as their targets (Tsuchiya 2015). In order to survive, all organisms need some version of a sense of pain which is perceived via their organism-specific sentience.

\section{References}

Baluška, F., Yokawa, K., Mancuso, S., \& Baverstock, K. (2016). Understanding of anesthesia - why consciousness is essential for life and not based on genes. Communicative \& Integrative Biology 9, e1238118.

Bernard, C. (1878). Leçons sur les phénomènes de la vie communs aux animaux et aux végétaux. (Librairie J.-B. Baillière et Fils).

Calvo, P., Sahi, V.P., \& Trewavas, A. (2017). Are plants sentient? Plant and Cell Environment 40, 2858-2869.

Gagliano, M. (2017). The mind of plants: Thinking the unthinkable. Communicative \& Integrative Biology 10, e1288333.

Grémiaux, A., Yokawa, K., Mancuso, S., \& Baluška, F. (2014). Plant anesthesia supports similarities between animals and plants: Claude Bernard's forgotten studies. Plant Signaling \& Behavior 9, e27886.

Koch, C. (2018). What is consciousness? Nature 557, S9-S12.

Lopez-Luna, J., Al-Jubouri, Q., Al-Nuaimy, W., \& Sneddon, L.U. (2017a). Reduction in activity by noxious chemical stimulation is ameliorated by immersion in analgesic drugs in zebrafish. Journal of Experimental Biology 220, 1451-1458.

Lopez-Luna, J., Al-Jubouri, Q., Al-Nuaimy, W., \& Sneddon, L.U. (2017b). Impact of analgesic drugs on the behavioural responses of larval zebrafish to potentially noxious temperatures. Applied Animal Behaviour Science 188, 97-105. 
Neiffer, D.L., \& Stamper, M.A. (2009). Fish sedation, anesthesia, analgesia, and euthanasia: considerations, methods, and types of drugs. ILAR Journal 50, 343-360.

Rinaldi, A. (2014). Reawakening anaesthesia research. EMBO Reports 15, 1113-1118.

Sneddon, L.U. (2012). Clinical anesthesia and analgesia in fish. Journal of Exotic Pet Medicine 21, 32-43.

Sneddon, L.U., Lopez-Luna, J., Wolfenden, D.C.C., Leach, M.C., Valentim, A.M., Steenbergen, P. J., Bardine, N., Currie, A.D., Broom, D.M., \& Brown, C. (2018). Fish sentience denial: Muddying the waters. Animal Sentience 21(1).

Trewavas, A.J., \& Baluška, F. (2011). The ubiquity of consciousness. EMBO Reports 12, 12211225.

Tsuchiya, H. (2015). Membrane interactions of phytochemicals as their molecular mechanism applicable to the discovery of drug leads from plants. Molecules 20, 18923-18966.

Tsuchiya, H. (2017). Anesthetic agents of plant origin: A review of phytochemicals with anesthetic activity. Molecules 22, 1369.

Yokawa, K., Kagenishi, T., Pavlovič, A., Gall, S., Weiland, M., Mancuso, S., \& Baluška, F. (2018). Anesthetics stop diverse plant organ movements, affect endocytic vesicle recycling, ROS homeostasis, and block action potentials in Venus flytraps. Annals of Botany, mcx155. 


\section{UQÀM/ISC Cognitive Science Summer School June 26 - July 6 2018, Montreal, Canada The Other Minds Problem: Animal Sentience and Cognition}

Overview. Since Descartes, philosophers know there is no way to know for sure what — or whether — others feel (not even if they tell you). Science, however, is not about certainty but about probability and evidence. The 7.5 billion individual members of the human species can tell us what they are feeling. But there are 9 million other species on the planet (20 quintillion individuals), from elephants to jellyfish, with which humans share biological and cognitive ancestry, but not one other species can speak: Which of them can feel — and what do they feel? Their human spokespersons - the comparative psychologists, ethologists, evolutionists, and cognitive neurobiologists who are the world's leading experts in "mind-reading" other species - will provide a sweeping panorama of what it feels like to be an elephant, ape, whale, cow, pig, dog, bat, chicken, fish, lizard, lobster, snail: This growing body of facts about nonhuman sentience has profound implications not only for our understanding of human cognition, but for our treatment of other sentient species.

Gregory Berns: Decoding the Dog's Mind with Awake Neuroimaging

Gordon Burghardt: Probing the Umwelt of Reptiles

Jon Sakata: Audience Effects on Communication Signals

PANEL: Reptiles, Birds and Mammals

WORKSHOP: Kristin Andrews: The "Other" Problems: Mind,

Behavior, and Agency

Sarah Brosnan: How Do Primates Feel About Their Social Partners?

Alexander Ophir: The Cognitive Ecology of Monogamy

Michael Hendricks: Integrating Action and Perception in a Small Nervous System

PANEL: Primates, Voles and Worms

WORKSHOP: Jonathan Birch: Animal Sentience and the

Precautionary Principle

Malcolm MacIver: $\underline{\text { How Sentience Changed After Fish Invaded }}$ Land 385 Million Years Ago

Sarah Woolley: Neural Mechanisms of Preference in Female Songbird

Simon Reader: Animal Social Learning: Implications for Understanding Others

PANEL: Sea to Land to Air

WORKSHOP: Steven M. Wise: Nonhuman Personhood

Tomoko Ohyama: Action Selection in a Small Brain

(Drosophila Maggot)

Mike Ryan: "Crazy Love": Nonlinearity and Irrationality in Mate Choice

Louis Lefebvre: Animal Innovation: From Ecology to

Neurotransmitters

PANEL: Maggots, Frogs and Birds: Flexibility Evolving

SPECIAL EVENT: Mario Cyr: Polar Bears

Colin Chapman: Why Do We Want to Think People Are

Different?

Vladimir Pradosudov: Chickadee Spatial Cognition

Jonathan Balcombe: The Sentient World of Fishes

PANEL: Similarities and Differences

WORKSHOP (part 1): Gary Comstock: $\underline{\text { A Cow's Concept of }}$ Her Future

WORKSHOP (part 2): Jean-Jacques Kona-Boun: Physical and Mental Risks to Cattle and Horses in Rodeos

Joshua Plotnik: Thoughtful Trunks: Application of Elephant
Cognition for Elephant Conservation

Lori Marino: Who Are Dolphins?

PANEL: Mammals All, Great and Small

Larry Young: The Neurobiology of Social Bonding, Empathy and Social Loss in Monogamous Voles

WORKSHOP: Lori Marino: The Inconvenient Truth About Thinking Chickens

Andrew Adamatzky: Slime Mould: Cognition Through Computation

Frantisek Baluska \& Stefano Mancuso: What a Plant Knows and Perceives

Arthur Reber: A Novel Theory of the Origin of Mind: Conversations With a Caterpillar and a Bacterium

PANEL: Microbes, Molds and Plants

WORKSHOP: Suzanne Held \& Michael Mendl: Pig Cognition and Why It Matters

James Simmons: What Is It Like To Be A Bat?

Debbie Kelly: Spatial Cognition in Food-Storing

Steve Phelps: Social Cognition Across Species

PANEL

WORKSHOP: To be announced

Lars Chittka: The Mind of the Bee

Reuven Dukas: Insect Emotions: Mechanisms and Evolutionary Biology

Adam Shriver: Do Human Lesion Studies Tell Us the Cortex is Required for Pain Experiences?

PANEL

WORKSHOP: Delcianna Winders: Nonhuman Animals in Sport and Entertainment

Carel ten Cate: Avian Capacity for Categorization and Abstraction

Jennifer Mather: Do Squid Have a Sense of Self?

Steve Chang: Neurobiology of Monkeys Thinking About Other Monkeys

PANEL

WORKSHOP: The Legal Status of Sentient Nonhuman Species 